\title{
Apresentação: Literatura LGBT+
}

\author{
Presentation: LGBT+ Literature \\ Presentación: literatura LGBT+ \\ Amara Moira ${ }^{*}$ \\ Tatiana Nascimento*
}

A crescente produção brasileira de narrativas literárias sobre dissidências sexuais e de gênero tem complexificado enormemente a forma como sujeitos e subjetividades LGBTQIA+ são representados, fazendo com que as imagens tradicionamente empregadas para pensar nossa condição - como o silêncio, o armário e a violência - já não deem conta de expressar (se é que um dia deram) a pluralidade de existências que se encontram sob esse guarda-chuva (Lopes, 2002; Trevisan, 2018). Tendo isso em mente, a proposta da presente seção temática foi, então, explorar a radicalidade dessas produções que têm despontado nos últimos anos, mas também promover a renovação do instrumental crítico e teórico de que dispomos para interpretar obras desse gênero e, de maneira ampla, a própria literatura contemporânea.

A expectativa é que cada vez seja menos possível falar em literatura brasileira, especialmente a da segunda metade do século $X X$ para cá, sem percebermos as produções de temática e autoria LGBTQIA+ como centrais para sua compreensão. Espera-se, além disso, que este dossiê colabore para que a intimidade com as questões LGBTQIA+ passe a ser percebida como fundamental não só para o entendimento dessas específicas obras, como também do restante da produção literária, isto é, as de autoria e temática marcadamente cisgêneras e heterossexuais (Santiago, 2004).

Indicativo disso é o fato de que aqui se encontram artigos tanto sobre figuras bastante consagradas das nossas Letras, quanto sobre outras que começaram a publicar apenas nos últimos quinze anos, mais da metade dos artigos tendo por objeto central obras que vieram a lume de 2016 para cá. Sirvam de exemplo do primeiro caso as análises intrigantes de Richard Leonardo Loayza sobre a dissidência sexual em Cartas de um sedutor (1991), da paulista Hilda Hilst (1930-2004), reveladoras de uma autora que tem muito a ganhar se lida pelas lentes dos estudos queer, assim como as investigações de Evandro Ramos de Sant'Anna Junior sobre corporalidades insubmissas, inclassificáveis, e a noção de profanação em dois romances do sulrio-grandense João Gilberto Noll (1946-2017): Berkeley em Belagio (2002) e Acenos e afagos (2008).

Com relação às obras mais recentes, destacam-se as considerações de Rosina Mattia sobre O amor dos homens avulsos (2016), do carioca Victor Heringer (1988-2018), e de Júlia Braga Neves sobre Controle (2019), da sul-rio-grandense Natalia Borges Polesso (1981), obras que têm em comum o fato de colocarem em cena protagonistas LGBTQIA+ cujas vidas são afetadas, respectivamente, pelo capacitismo e pela psicofobia, condições que, para além de outros tantos atravessamentos como gênero, idade, raça/etnia, classe social, mostram o quanto nossas existências não se resumem ao pertencimento a essa sigla.

Natalia Borges Polesso faz-se ainda presente no volume com um artigo de autoria própria, convidando-nos a uma necessária reflexão sobre o que ela denominou "geografia lésbica" (escrito exatamente assim, forma encontrada pela autora para problematizar, mais do que definir, o objeto dessa "geografia") e sobre esses tantos atravessamentos que, junto à questão das dissidências gênero-sexuais, nos compõem. Ponto importante de seu texto é a discussão a respeito do rotular-se como "escritora lésbica", no que se aproxima do debate trazido por

\footnotetext{
" Universidade Estadual de Campinas (Unicamp), Campinas, SP, Brasil. (Dorcid.org/0000-0003-2229-8103. E-mail : amoiramara@gmail.com

*** Universidade de Brasília (UnB), Brasília, DF, Brasil. (Dorcid.org/0000-0003-1986-2033. E-mail: palavrapreta@ gmail.com
} 
Ágnes Souza ao examinar as obras Um útero é do tamanho de um punho (2013), da sul-riograndense Angélica Freitas, e Quase todas as manhãs (2016), da fluminense Simone Brantes.

Claudicélio Rodrigues da Silva também aborda a questão das tensões entre autoria e temática LGBTQIA+ ao analisar os critérios da antologia Poesia gay brasileira (2017), das mineiras Amanda Machado e Marina Moura, mas seu maior interesse recai sobre as práticas sexuais contra-hegemônicas presentes em alguns dos poemas ali recolhidos.

A análise de Dorinaldo dos Santos Nascimento sobre a obra autobiográfica As flores do jardim da nossa casa (2007), do mineiro Marco Lacerda, traz à baila o universo dos garotos de programa e um debate atualíssimo sobre masculinidades e mercado do sexo. A travesti paulista Amara Moira, uma das organizadoras deste dossiê, tem sua obra autobiográfica $E$ se eu fosse puta (2016) examinada por Leandro de Souza Borges Silva e Ricardo Oliveira de Freitas, que apresentam um artigo a respeito da forma como, nessa obra, o espaço urbano se desenha.

Por fim, uma inovadora abordagem de Renata Barreto Malta, Carina Luisa Ochi Flexor e Arianne Amado Nunes Costa sobre tensionamentos entre política e literatura, tendo como foco milhares de comentários feitos numa publicação do YouTube em função, por um lado, dos esforços do prefeito Marcelo Crivella para censurar publicações de temática LGBTQIA+ na Bienal do Livro do Rio de Janeiro em 2019 e, por outro, das ações comandadas pelo influenciador digital Felipe Neto em resposta a tal tentativa de censura.

Já em 2005, ao divulgar os resultados da primeira parte da pesquisa "Personagens do romance brasileiro contemporâneo, a professora Regina Dalcastagnè identificava: "Nosso campo literário é um espaço excludente, constatação que não deve causar espanto, já que ele se insere num universo social que é também extremamente excludente" (2005, p. 63-64). Os dados da referida pesquisa apontavam que o perfil do romancista brasileiro contemporâneo era o de autores em sua esmagadora maioria homens, brancos, de classe média, heterossexuais e nascido no eixo Rio-São Paulo. Diante dessa constatação, era impossível não refletir sobre a invisibilização e o silenciamento a que estavam submetidos determinados grupos e perspectivas sociais.

Ainda que de lá para cá o mercado literário continue bastante conservador, é preciso comemorar que, nos últimos anos, houve um crescimento exponencial de escritos de autoria LGBTQIA+, que vêm ocupando espaço, sobretudo, por meio de editoras independentes. Em suas múltiplas interseç̧ões com raça/etnia, gênero e classe social, essas vozes/narrativas dissidentes se avolumam nas páginas de nossa literatura, contrariando a ortodoxia heterocêntrica e cisnormativa que historicamente a constituiu.

Resta investigar se a crítica literária tem sido capaz de acompanhar esse movimento. Para este dossiê, a Estudos de Literatura Brasileira Contemporânea recebeu um total de 29 artigos, dos quais 2 foram posteriormente retirados a pedido dos próprios autores. Dos 27 artigos restantes, 9 foram rejeitados na triagem inicial, quer seja por não se adequarem ao recorte da revista ou por ainda não estarem suficientemente amadurecidos para publicação em um periódico de excelência. Dos 18 artigos que seguiram para avaliação por pares, 10 foram aprovados e aqui compõem este dossiê como uma pequena amostra do que a crítica vem produzindo a respeito do tema.

Ao visitar esses artigos e examinar a lista de obras exploradas, observa-se que a autoria/temática em evidência ainda é eminentemente branca, oriunda do Sul/Sudeste, das classes médias brasileiras e pouco íntima dos debates sobre questões tanto raciais quanto trans. Assim, esse pequeno recorte revela que, mesmo com a complexificação das representações apontada nos artigos, o que se vê é ainda uma fatia limitada das narrativas e existências LGBTQIA+, diante da ausência de outros marcadores identitários, tais como raça/etnia e regionalidade. Saudamos, então, as novidades que se fazem notar nos artigos aqui presentes, mas apontamos também para a necessidade urgente de instigarmos que esse debate seja trazido para dentro das universidades de forma cada vez mais interseccional. 


\section{Referências}

DALCASTAGNÈ, Regina (2005). A personagem do romance brasileiro contemporâneo (19902004). Estudos de Literatura Brasileira Contemporânea, Brasília, n. 26, p. 13-71.

LOPES, Denilson (2002). O homem que amava rapazes e outros ensaios. Rio de Janeiro: Aeroplano.

SANTIAGO, Silviano (2004). O homossexual astucioso: primeiras - e necessariamente apressadas anotações. In: SANTIAGO, Silviano. O cosmopolitismo do pobre: crítica literária e crítica cultural. Belo Horizonte: Editora UFMG. p.193-203.

TREVISAN, João Silvério (2018). Devassos no paraíso: a homossexualidade no Brasil, da colônia à atualidade. 4 . ed. Rio de Janeiro: Objetiva. 